\title{
The effects of nedocromil sodium on the response to grain dust in West Australian grain workers
}

\author{
A D Blainey, A W Musk, G Ryan, M J Phillips, C Buccilli, S Troon, G Kidd
}

\begin{abstract}
Seasonal grain workers in Western Australia who develop respiratory symptoms after exposure to grain dust develop concomitant changes in lung function and bronchial responsiveness to methacholine. The mechanisms underlying these changes are not known. A detailed study was undertaken of seasonal grain workers in Western Australia to evaluate the effect of nedocromil sodium (Fisons, United Kingdom) on these changes to see if they could be prevented by this drug. Forty seven subjects participated. Symptoms and forced expiratory volume in one second $\left(F E V_{1}\right)$ were recorded before the study and before, during, and after each working shift, and bronchial responsiveness to methacholine was measured at the beginning and end of the study. Twenty three subjects received nedocromil and 22 received a placebo in a double blind design; there was no difference in baseline characteristics between the two groups. At the end of the study, no differences were found between the nedocromil and placebo groups in the prevalence of symptoms or development of new symptoms during the study. The drug had no effect on changes in methacholine $\mathbf{P D}_{20}$ or $\mathrm{FEV}_{1}$. As in previous studies, new symptoms developing during the season were more common in atopic subjects and were associated with a fall in methacholine $\mathbf{P D}_{20}$. It is concluded that nedocromil has no effect on the development of new symptoms in grain workers. The mechanisms underlying these symptoms require further study.
\end{abstract}

Grain dust has both acute and long term effects on the airways. ${ }^{1-5} \mathrm{~A}$ few affected subjects develop allergic asthma (due to durum wheat, ${ }^{6}$ storage mites, ${ }^{7}$ or unknown allergens ${ }^{8}$ ) but in general the mechanisms

Respiratory Department, Sir Charles Gairdner Hospital, Nedlands, Western Australia 6009, Australia

A D Blainey, A W Musk, G Ryan, M J Phillips, C Buccilli, $S$ Troon, G Kidd responsible for these effects have not been established. Studies in seasonal workers in the Western Australia grain industry have shown that symptoms developing in subjects newly exposed to grain are associated with a fall in forced expiratory volume in one second $\left(\mathrm{FEV}_{1}\right)$ and increased bronchial responsiveness. These changes appear soon after exposure at work and do not result from the presence of asthma, which is rare.$^{910}$ Bronchial responsiveness is also increased in grain workers without allergic asthma. ${ }^{11}$ These observations suggest that inflammation of airways, perhaps implicating mast cells, may contribute to the development of obstruction of airways in grain workers.

It is difficult to obtain direct evidence of a contribution from mast cells and inflammatory processes in responses of airways to natural environmental exposures. The response to drugs which suppress release of inflammatory mediators may provide indirect evidence for these mechanisms. The present study reports the effects of nedocromil sodium (Fisons, Loughborough, United Kingdom) on the respiratory response to grain dust in Western Australian grain workers. Nedocromil is a stabilising agent for mast cells, with similar effects to sodium cromoglycate. ${ }^{12}$ It is effective in the prevention of allergen induced bronchospasm and in the treatment of asthma. ${ }^{1314}$ The effects of this drug have been compared with a placebo in a double blind comparison in 47 employees of a grain depot during the 1986-7 grain season.

\section{Subjects and methods}

SUBJECTS AND WORKPLACE

Workers were studied at one grain depot in central Western Australia. The depot is a major inland transfer point for grain grown in the central Western Australian wheatbelt. Most grain arrives by rail and is transferred through conveyors to temporary storage in concrete silos before being transferred to other railway wagons for transport to the docks. Peak activity at the depot is from November to January. During this time, the small permanent staff is augmented by workers employed for the season.

Seventeen permanent staff and 30 seasonal staff volunteered to participate. This represented $94 \%$ of 
the seasonal workers and $59 \%$ of the permanent workforce employed at the plant for the duration of the study. No details were available on the 12 permanent workers and two seasonal workers who declined to take part.

Workers were employed in several different locations in the plant (see table 1). Most moved from job to job within the plant daily or weekly; only supervisory staff remained in the same job for the duration of the study. At the peak of the season employees worked a day shift (7.00 am to $6.00 \mathrm{pm})$ or a night shift ( $7.00 \mathrm{pm}$ to $3.00 \mathrm{am})$. A week of days preceded a week of nights. Informed consent for the study was obtained in writing from each participant and the study was approved by the human rights committee of the Sir Charles Gairdner Hospital.

\section{METHODS}

At the beginning of the study, subjects were asked to complete a baseline questionnaire, and pulmonary function and bronchial responsiveness to methacholine were measured. Subjects were randomly assigned to receive either nedocromil or placebo from a metered dose inhaler. Subjects reported to the survey team three times during each shift throughout the study. On each occasion, symptoms arising since the last visit were recorded, spirometry was performed, and two puffs of nedocromil or placebo were administered in a double blind design. Bronchial responsiveness was measured at the beginning of the study, after four weeks, and at the end of the study. The study was planned to last six weeks.

\section{QUESTIONNAIRE}

The questionnaire, modified from a Medical Research Council version, with additional questions relating to occupational exposure and to allergic

Table 1 Job locations and dust concentrations

\begin{tabular}{|c|c|c|}
\hline & \multicolumn{2}{|c|}{ Grain dust concentrations } \\
\hline & $\begin{array}{l}\text { No of } \\
\text { samples }\end{array}$ & $\begin{array}{l}\text { Mean dust } \\
\text { concentrations } \\
m g / m^{3} \text { (range) }\end{array}$ \\
\hline $\begin{array}{l}\text { Grid and loading: } \\
\text { Direct loading and unloading } \\
\text { rail wagons and trucks }\end{array}$ & 23 & $\begin{array}{l}3 \cdot 72 \\
(0 \cdot 46-62 \cdot 15)\end{array}$ \\
\hline $\begin{array}{l}\text { Under rail: } \\
\text { Basement, direct unloading } \\
\text { rail wagons }\end{array}$ & 6 & $\begin{array}{l}2 \cdot 42 \\
(0 \cdot 62-7 \cdot 0)\end{array}$ \\
\hline $\begin{array}{l}\text { Over cells: } \\
\text { Top floor conveyers }\end{array}$ & 6 & $\begin{array}{l}2 \cdot 16 \\
(0 \cdot 55-5 \cdot 75)\end{array}$ \\
\hline $\begin{array}{l}\text { Capstans: } \\
\text { Loading and unloading; } \\
\text { less close than Grid }\end{array}$ & 10 & $\begin{array}{l}1 \cdot 74 \\
(0 \cdot 16-14 \cdot 21)\end{array}$ \\
\hline $\begin{array}{l}\text { Shed storage: } \\
\text { Bulldozer handling of } \\
\text { floor stored grain }\end{array}$ & 6 & $\begin{array}{l}8.02 \\
(3.63-30.01)\end{array}$ \\
\hline $\begin{array}{l}\text { Control areas: } \\
\text { Scattered throughout } \\
\text { plant }\end{array}$ & 6 & $\begin{array}{l}0.79 \\
(0.34-3.24)\end{array}$ \\
\hline
\end{tabular}

symptoms, was presented to participants by trained interviewers to record symptoms occurring before the start of the study. Smoking and occupational histories were also recorded. Current smokers were defined as those who had smoked at least one cigarette a day for more than one year, and exsmokers were defined as those who had smoked this much in the past but had not smoked for one year before the start of the study. Symptoms of cough, wheeze, breathlessness, and chest tightness were recorded on each subject at the beginning, middle, and end of each shift. These were graded from none (0) to severe (3). Unusual symptoms or adverse effects of the drug were recorded at the same time. Symptoms recorded in the 12 hours after challenge with methacholine were not included in the analysis.

\section{SPIROMETRY}

Forced expiratory volume in one second $\left(\mathrm{FEV}_{1}\right)$ and forced vital capacity (FVC) were measured on one of three dry bellows spirometers (Vitalograph, Bucks, United Kingdom). Three recordings within $5 \%$ or $100 \mathrm{ml}$ were obtained from each subject at the start of the study and at each visit to the survey team during each shift at the same time as their symptoms were recorded. The spirometers were calibrated at regular intervals using a one litre calibrating syringe, and each subject was always tested on the same spirometer.

BRONCHIAL RESPONSIVENESS TO METHACHOLINE

Bronchial responsiveness to methacholine was measured in 46 subjects by the method of Yan et al. ${ }^{15}$ Methacholine was administered in increasing concentrations from a deVilbiss No $\mathbf{4 0}$ hand held glass nebuliser (deVilbiss, Somerset, Pa, USA), until the $\mathrm{FEV}_{1}$ had fallen by $20^{\circ}$ of the lowest value after saline control inhalation (methacholine $\mathrm{PD}_{20}$ is the dose provoking the $20^{\circ}{ }_{0}$ fall) or until the maximum dose of $100.8 \mu \mathrm{mol}$ methacholine (representing a concentration of $400 \mathrm{mg} / \mathrm{ml}$ ) had been reached. Bronchoconstriction was reversed with a salbutamol inhaler. The $\mathrm{PD}_{20}$ was derived by linear interpolation.

\section{SKIN PRICK TESTS}

Skin prick tests were performed according to the method described by Pepys. ${ }^{16}$ Extracts of common domestic inhalant allergens were used to detect atopic subjects who were defined as having one or more positive skin tests ( $>3 \mathrm{~mm}>$ negative control) to one of the following allergens: Dermatophagoides pteronyssinus, $1 \%$ w/v; Dermatophagoides farinae, $1: 55 \mathrm{w} / \mathrm{v}$; rye grass pollen extract, $1: 10 \mathrm{w} / \mathrm{v}$; mixed moulds (Aspergillus fumigatus, Alternaria); cat epithelium dander $10 \% \mathrm{w} / \mathrm{v}$ (Hollister Stier). Histamine $(10 \mu \mathrm{g} / \mathrm{ml})$ was used as a positive control. 


\section{ADMINISTRATION OF DRUGS}

Nedocromil or placebo was administered to each subject from a metered dose inhaler delivering $2 \mathrm{mg}$ of nedocromil at each actuation; $4 \mathrm{mg}$ were administered at each visit by a member of the survey team. Drugs were given three times during each shift, but were not given on the days when the subjects were not at work.

\section{DUST EXPOSURE}

Individual dust exposure was measured using personal samplers supplied by the Department of Occupational Safety and Health of the Government of Western Australia. Preweighed 0.5 $\mu$ PVC filters were used in $37 \mathrm{~mm}$ single hole samplers attached to a Dupont 2500A constant flow pump. Filters were weighed after equilibration in the laboratory. Measurements were made on 61 shifts, representing most jobs in the plant, to obtain average dust concentrations over the period of the shift, or part of the shift, if the dust concentration was very high (minimum recording time two hours). At each visit to the survey team, subjects were asked to record their estimated dust exposure since their last visit to provide a subjective estimate of intensity. The response was graded from 1 (no dust) to 5 (very high dust concentrations).

\section{STATISTICAL METHODS}

Data were entered onto computer files and manually checked against the originals. Both parametric and non-parametric methods were used to analyse the results, and methacholine $\mathrm{PD}_{20}$ values were logarithmically transformed for analysis. Measurements of lung function were compared using Student's $t$ test. Analysis of variance was carried out for changes in $\mathrm{FEV}_{1}$ using subjects as a grouping factor and day or night and exposure levels as within factors, and also using subjects as a grouping factor and day or night and day of the week as within factors. Symptom scores were compared by Mann-Whitney U tests.

\section{Results}

Forty seven subjects-17 permanent and 30 seasonal workers-agreed to participate in the study; 24 subjects were randomly allocated to receive nedocromil and 23 subjects to receive placebo. The groups were evenly matched in age, initial lung function, smoking history, atopic state, and methacholine $\mathrm{PD}_{20}$ (table 2).

Two subjects withdrew after only one day of treatment and were excluded from the analysis, leaving 23 in the nedocromil treated group and 22 in the placebo group. The subject taking nedocromil withdrew because of nausea, and the subject taking placebo withdrew because of cough and dyspnoea.
Table 2 Characteristics of subjects

\begin{tabular}{|c|c|c|}
\hline & Nedocromil group & $\begin{array}{l}\text { Placebo } \\
\text { group }\end{array}$ \\
\hline $\begin{array}{l}\text { No of subjects } \\
\text { Mean age (y) } \\
\text { (range) }\end{array}$ & $\begin{array}{l}24 \\
28 \cdot 1 \\
(17-56)\end{array}$ & $\begin{array}{l}23 \\
27 \cdot 3 \\
(17-51)\end{array}$ \\
\hline \multicolumn{3}{|l|}{ Smoking habit: } \\
\hline Never smoked & 10 & 7 \\
\hline Ex-smoker & 0 & 4 \\
\hline Current smoker & 14 & 12 \\
\hline Atopic & 9 & 12 \\
\hline $\begin{array}{l}\text { Initial FEV } \text { (range) }^{(} \text {o predicted) } \\
\text { (rise }\end{array}$ & $\begin{array}{l}88 \cdot 4 \\
(61.9-109)\end{array}$ & $\begin{array}{l}96 \cdot 2 \\
(73 \cdot 0-115)\end{array}$ \\
\hline $\begin{array}{l}\left.\text { Initial FVC ( }{ }^{\circ} \circ \text { predicted }\right) \\
\text { (range) }\end{array}$ & $\begin{array}{l}96 \cdot 7 \\
(71 \cdot 0-114)\end{array}$ & $\begin{array}{l}101 \cdot 4 \\
(72 \cdot 9-127\end{array}$ \\
\hline $\begin{array}{l}\text { Methacholine } \mathrm{PD}_{20} \text { (mean } \\
\text { baseline; } \mu \mathrm{mol} \text { ) }\end{array}$ & $22 \cdot 5$ & $22 \cdot 2$ \\
\hline
\end{tabular}

\section{SYMPTOMS}

Table 3 shows the prevalence and type of symptoms reported at any time during the study. Cough was the commonest symptom reported on a daily basis; other symptoms were less frequent. Mean symptom scores were low, showing that symptoms were reported by only a few subjects and were almost invariably graded as mild. There was no significant difference between treated and placebo groups in the prevalence of symptoms or symptom scores. Many of the symptoms that were reported had been recorded by the subjects in the initial questionnaire and could not be specifically related to exposure to grain dust. Table 4 shows symptoms not reported on the initial questionnaire. Fifteen subjects reported such new symptoms, with cough again the most frequent. New symptoms were more common in seasonal workers $(12 / 28)$ than permanent workers (3/17) but this difference did not reach the $5 \%$ level of significance. There was no difference in the prevalence of symptoms between nedocromil and placebo treated groups. New symptoms were significantly more likely to occur in atopic subjects $\left(\chi^{2}=4.5, \mathrm{p}<0.05\right)$ and in subjects with a greater than twofold fall in bronchial responsiveness $\left(\chi^{2}=9.504, p<0.01\right)$ but were not associated with cigarette smoking.

\section{LUNG FUNCTION}

Mean FEV, fell over the course of the study by 100 $\mathrm{ml}$ in the nedocromil treated group and $30 \mathrm{ml}$ in the placebo treated group. Mean FVC fell by $80 \mathrm{ml}$ in the

Table 3 Prevalence of respiratory symptoms during study

\begin{tabular}{|c|c|c|c|c|}
\hline & \multicolumn{2}{|c|}{$\begin{array}{l}\text { Nedocromil group } \\
(n=23)\end{array}$} & \multicolumn{2}{|c|}{$\begin{array}{l}\text { Placebo group } \\
(n=22)\end{array}$} \\
\hline & $\begin{array}{l}\text { Prevalence } \\
(\%)\end{array}$ & $\begin{array}{l}\text { Mean } \\
\text { symptom } \\
\text { score }\end{array}$ & $\begin{array}{l}\text { Prevalence } \\
(\%)\end{array}$ & $\begin{array}{l}\text { Mean } \\
\text { symptom } \\
\text { score }\end{array}$ \\
\hline $\begin{array}{l}\text { Cough } \\
\text { Wheeze } \\
\text { Dyspnoea } \\
\text { Chest tightness }\end{array}$ & $\begin{array}{r}60.9 \\
13 \cdot 0 \\
8 \cdot 7 \\
8.7\end{array}$ & $\begin{array}{l}0.34 \\
0.01 \\
0.01 \\
0.01\end{array}$ & $\begin{array}{l}47 \cdot 6 \\
0 \\
4 \cdot 8 \\
4 \cdot 8\end{array}$ & $\begin{array}{l}0 \cdot 20 \\
0 \\
0 \cdot 04 \\
0 \cdot 002\end{array}$ \\
\hline
\end{tabular}


Table 4 New respiratory symptoms not reported at initial survey

\begin{tabular}{lll}
\hline & $\begin{array}{l}\text { Nedocromil } \\
\text { group } \\
(n=9)\end{array}$ & $\begin{array}{l}\text { Placebo } \\
\text { group } \\
(n=6)\end{array}$ \\
\hline Cough (No of subjects) & 8 & 5 \\
Wheeze (No of subjects) & 2 & 0 \\
Dyspnoea (No of subjects) & 1 & 0 \\
Chest tightness (No of subjects) & 1 & 0 \\
\hline
\end{tabular}

nedocromil group and $300 \mathrm{ml}$ in the placebo group. The differences between the start and finish of the study and between nedocromil and placebo treated groups were not significantly different.

Table 5 shows the shift related change in $\mathrm{FEV}_{1}$ $\left(\triangle F E V_{1}\right)$. No difference was found between nedocromil and placebo treated groups. During the day shift, however, $\mathrm{FEV}_{1}$ rose significantly in both groups and fell significantly during the night shift in both groups. The difference between changes in $\mathrm{FEV}_{1}$ for days and nights was highly significant. There was no effect of the working week after allowing for the effect of time of day. Only one subject showed a consistent daytime fall in $\mathrm{FEV}_{1}$. No correlation was found between symptom scores and $\triangle \mathrm{FEV}_{1}$ for each subject.

BRONCHIAL RESPONSIVENESS TO METHACHOLINE

Methacholine $\mathrm{PD}_{20}$ fell by $6.9 \mu \mathrm{mol}$ in the nedocromil treated group and $2.3 \mu \mathrm{mol}$ in the placebo group over the period of the study. This difference was not statistically significant. There was no overall correlation between change in methacholine $\mathrm{PD}_{20}$ and symptom scores. Sixteen subjects, however, had a greater than twofold fall in methacholine $\mathrm{PD}_{20}$ during the study period, of whom 10 had described new symptoms. This association between new symptoms and $\mathrm{PD}_{20}$ was significant $(\mathrm{p}<0.01)$ and in these 10 subjects mean $\mathrm{PD}_{20}$ fell from $18.4 \mu \mathrm{mol}$ to $5.64 \mu \mathrm{mol}$.

\section{EXPOSURE TO GRAIN DUST}

Table 1 shows the mean and range of recorded dust exposure concentrations from 62 samples. Ten recordings $(16 \cdot 1 \%)$ were greater than $10 \mathrm{mg} / \mathrm{m}^{3}$ and

Table 5 Shift related change in FEV,

\begin{tabular}{|c|c|c|}
\hline & $\begin{array}{l}\text { Nedocromil } \\
\text { group } \\
F E V_{1}(l)(S D)\end{array}$ & $\begin{array}{l}\text { Placebo } \\
\text { group } \\
\text { FEV }(l)(S D)\end{array}$ \\
\hline $\begin{array}{l}\text { Overall mean change } \\
\text { Day shift only } \\
\text { Night shift only } \\
\text { Day shift (day one of week) } \\
\text { Day shift (day five of week) } \\
\text { Night shift }\end{array}$ & $\begin{array}{l}-0.004(0.075) \\
+0.115(0.080) \\
-0.140(0.110) \\
+0.077(0.167) \\
+0.151(0.139)\end{array}$ & $\begin{array}{l}+0.031(0.140) \\
+0.121(0.121) \\
-0.145(0.144) \\
+0.141(0.098) \\
+0.108(0.169)\end{array}$ \\
\hline $\begin{array}{l}\text { (day one of week) } \\
\text { Night shift } \\
\text { (day five of week) }\end{array}$ & $\begin{array}{l}-0.142(0.196) \\
-0.095(0.109)\end{array}$ & $\begin{array}{l}-0.136(0.153) \\
-0.140(0.159)\end{array}$ \\
\hline
\end{tabular}

$14(22.6 \%)$ were between $5 \mathrm{mg} / \mathrm{m}^{3}$ and $10 \mathrm{mg} / \mathrm{m}^{3}$. Jobs with the highest dust concentrations were storage sheds and direct loading or unloading, but within jobs there was a large range of dust exposures.

Because the variability within jobs was so great, self reported dust exposure concentrations rather than job exposures were used to study correlations with lung function and symptoms. The correlation between self reported dust exposure concentrations and recorded dust concentrations was significant $(\mathrm{r}=0.526, \mathrm{p}<0.01$; fig 1$)$.

\section{RELATION BETWEEN EXPOSURE TO DUST, LUNG} FUNCTION, AND SYMPTOMS

Figure 2 shows the prevalence of symptoms at each level of exposure to grain dust. No correlation existed between dust concentrations and the prevalence of symptoms or symptom scores $(r=0.06)$, in either nedocromil or placebo group. Dust exposure levels were not correlated with $\mathrm{FEV}_{1}$ for the day shift $(r=0.04)$ or the night shift $(r=0.01)$.

\section{EFFECTS OF ATOPY AND SMOKING}

There was no association between symptom scores and atopy within each treatment group or for the group as a whole $\left(\chi^{2}=2 \cdot 16, p>0 \cdot 05\right)$. As described

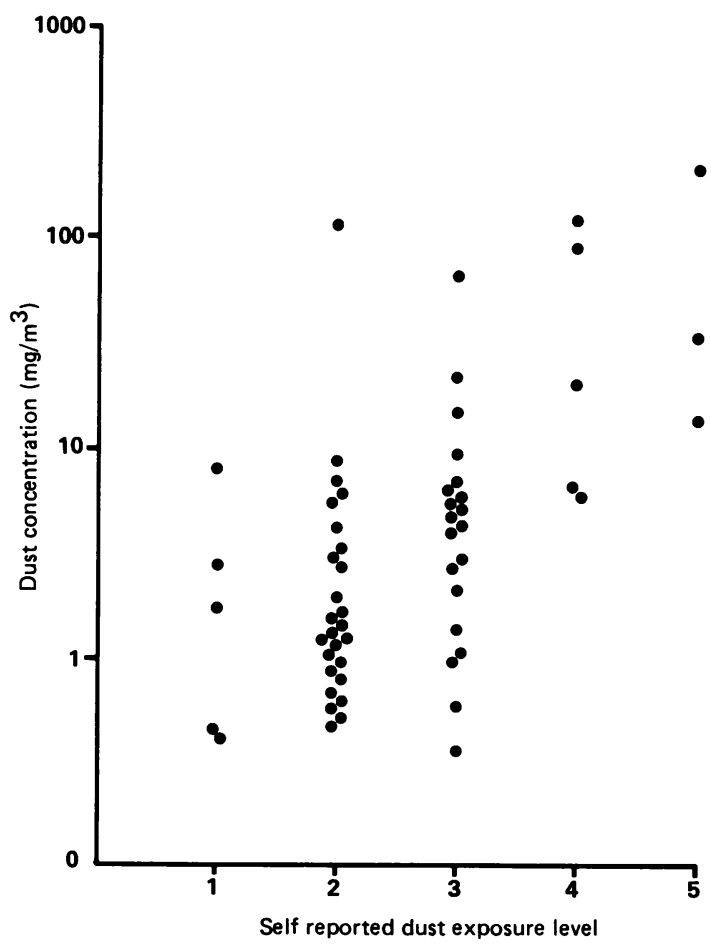

Figure 1 Relation between self reported and measured dust exposure concentrations. 


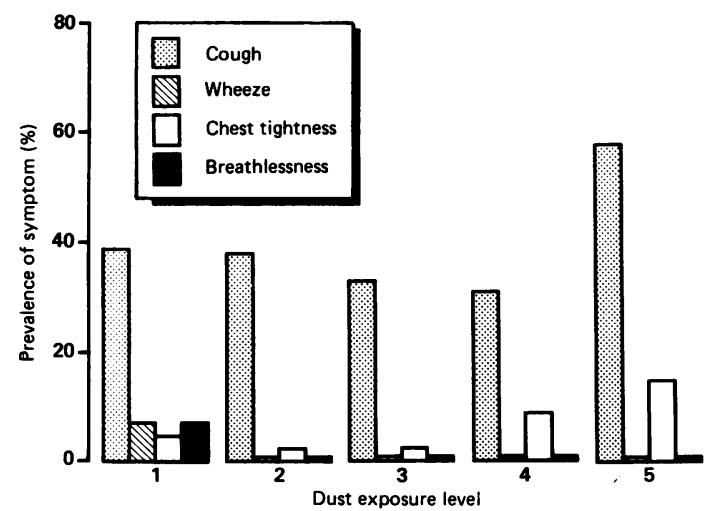

Figure 2 Relation between self reported dust exposure concentrations and prevalence of symptoms.

above, however, subjects with new symptoms were more likely to be atopic. Smoking was not related to symptom scores or to change in $\mathrm{PD}_{20}$. There was an association between shift related change in $\mathrm{FEV}_{1}$ and increased smoking in pack-years but only for the day shift $(r=0.31, p=0.04)$ and it should be noted that the same workers did both day and night shifts at different times and there was no evidence of association during the night shift.

\section{Discussion}

The present study confirms the results of previous surveys of West Australian grain workers. ${ }^{910}$ Those who developed symptoms for the first time during the season of maximum exposure to grain were more likely to be atopic and showed a significant fall in methacholine $\mathrm{PD}_{20}$. There was no change in $\mathrm{FEV}_{1}$ during the period of this study and no specifically shift related changes in $\mathrm{FEV}_{1}$. The observed differences between changes in $\mathrm{FEV}_{1}$ during the day and those during the night are likely to be due to the normal diurnal variation of airway calibre. ${ }^{17}$

The overall level of symptoms reported in this study was low, despite concentrations of grain dust comparable with those of other surveys in which symptoms and changes in lung function were more frequent. ${ }^{317}$ This may be because of differences in the grain itself, or to differences in working conditions. It is also possible that the period of exposure to grain in this study was too short to allow changes in lung function to develop, although in this and previous studies of seasonal grain workers symptoms and changes in bronchial reactivity occurred early rather than developing cumulatively over the course of the season.

Nedocromil had no effect on the overall prevalence of symptoms, or on the development of new symptoms. There was no effect on changes in $\mathrm{PD}_{20}, \mathrm{FEV}_{1}$, or $\mathrm{FEV}_{1}$ over a shift.
The mode of action of nedocromil is not precisely known. In primates it is a potent inhibitor of mast cells, ${ }^{12}$ it blocks antigen challenge and asthma induced by exercise, and is effective in the treatment of asthma. ${ }^{1314}$ It also inhibits bronchoconstriction induced by sulphur dioxide and bradykinin but has no effect on cough and bronchoconstriction induced by capsaicin. ${ }^{19-21}$

In this study, the association of new symptoms with atopy and changes in methacholine $\mathrm{PD}_{20}$ implies an inflammatory or possibly allergic mechanism. The lack of effect of nedocromil, however, suggests that allergen induced asthma is unlikely to be responsible. A reflex mechanism (perhaps similar to the effects of capsaicin) might be responsible, but this would not explain the changes in bronchial reactivity. It is possible that the present study was too short and had too few patients to demonstrate the effect of nedocromil, but the differences between placebo and treated groups were extremely small.

The mechanism underlying symptoms induced by grain dust remains uncertain. This study provides no evidence that grain dust has a byssinosis like effect in that there was no effect of time of week on changes in $\mathrm{FEV}_{1}$, and only one subject showed any daytime decline in $\mathrm{FEV}_{1}$. The most important influence on changes in $\mathrm{FEV}_{1}$ was time of day, and this clearly needs to be considered in all future studies of shift related change in $\mathrm{FEV}_{1}$ in grain workers.

The lack of correlation between exposure to grain dust and symptoms or methacholine $\mathbf{P D}_{20}$ suggests that these manifestations of respiratory disease induced by grain dust may not be precisely dose related. This observation, however, may also be the result of the way that symptoms were recorded. Symptoms which occurred after shifts had ended were recorded as being associated with zero exposure to grain, but symptoms developing after work (as commonly occurs in occupational asthma, for example) may be important. Also, the use of self reported dust exposure concentrations may not be as accurate as continuous measures of dust exposure, but continuous recordings were beyond the scope of this study.

We have confirmed other findings in West Australian grain workers-namely, that new symptoms were commoner in atopic subjects and associated with a fall in methacholine $\mathrm{PD}_{20}$. These changes were not accompanied by changes in $\mathrm{FEV}_{1}$ or $\mathrm{FEV}_{1}$ over a shift, and the most important influence on shift related change in $\mathrm{FEV}_{1}$ was time of day. Nedocromil had no effect on the prevalence of symptoms or on the development of new symptoms during the peak of the grain handling season and did not prevent changes in bronchial reactivity.

We are grateful to the management and workers at Northam grain depot, Western Australia, for their 
help and cooperation in this study. Statistical analysis was performed by Mr M Stevens and Rachel Blackshaw of the Statistical Department, Fisons, Loughborough, United Kingdom. We also thank Fisons (Loughborough, United Kingdom) and Fisons Pty (Australia) for financial support and for the supply of nedocromil.

Requests for reprints to: Dr A W Musk, Respiratory Department, Sir Charles Gairdner Hospital, Verdun St, Nedlands, Western Australia 6009, Australia.

1 Warren P, Cherniak RM, Tse KS. Hypersensitivity reactions to grain dust. J Allergy Clin Immunol 1974;53:139-49.

2 Broder I, Mintz S, Hutcheon M, et al. Comparison of respiratory variables in grain elevator workers and civic outside workers of Thunder Bay, Canada. Am Rev Respir Dis 1979;119:193-203.

3 Corey P, Hutcheon M, Broder I, Mintz S. Grain elevator workers show work-related pulmonary function changes and dose-effect relationships with dust exposure. $\mathrm{Br} J$ Ind Med 1982;39:330-7.

4 Cotton DJ, Graham BAL, Li KYR, et al. Effect of smoking and occupational exposure on peripheral airway function in young cereal grain workers. Am Rev Respir Dis 1982;126:660-5.

5 Enarson DA, Vedal S, Chan-Yeung S. Rapid decline in FEV , in grain handlers. Am Rev Respir Dis 1985;132:814-7.

6 doPico GA, Jacobs S, Flaherty D, Rankin J. Pulmonary reaction to durum wheat. Chest 1982;81:55-61.

7 Blainey AD, Topping MD, Ollier S, Davies RJ. Allergic Respiratory disease in grainworkers: the role of storage mites. $J$ Allergy Clin Immunol 1989;84:296-303.

8 Chan-Yeung $M$, Wong $R$, MacLean L. Respiratory abnormalities among grain elevator workers. Chest 1975;75:461-7.

9 Cookson WOCM, Ryan G, MacDonald S, Musk AW. Atopy, non-allergic bronchial reactivity, and past history as determinants of work-related symptoms in seasonal grain handlers. $\mathrm{Br}$
$J$ Ind Med 1986;43:396-400.

10 James AL, Cookson WOCM, Buters G, et al. Symptoms and longitudinal changes in lung function in young seasonal grain handlers. Br J Ind Med 1986;43:587-91.

11 Mink JT, Gerrard JW, Cockcroft DW, Cotton DJ, Dosman JA. Increased bronchial reactivity to histamine in nonsmoking grainworkers with normal lung function. Chest 1980; 77:28-31.

12 Eady RP, Greenwood B, Jackson DM, Orr TSC, Wells E. The effect of nedocromil sodium on antigen-induced bronchoconstriction in the Ascaris-sensitive monkey. $\mathrm{Br} J$ Pharmacol $1985 ; 85: 323-5$.

13 Shaw RJ, Kay AB. Nedocromil sodium, a mucosal and connective tissue mast cell stabiliser, inhibits exercise-induced asthma. Br J Dis Chest 1985;79:385-9.

14 Lal S, Mahotra S, Gribben D, Hodder D. Nedocromil sodium: a new drug for the management of bronchial asthma. Thorax 1984;39:809-12.

15 Yan K, Salome C, Woolcock AJ. A new method for the measurement of bronchial responsiveness. Thorax 1983; 38:760-5.

16 Pepys J. Skin tests in diagnosis. In: Gell PGH, Coombes RRA, Lachmann PJ, eds. Clinical aspects of immunology. Oxford: Blackwell, 1975.

17 doPico GA, Reddan W, Anderson S, Flaherty D, Smalley E. The acute effects of grain dust during a workshift. Am Rev Respir Dis 1983;128:399-404.

18 Youngchaigud $\mathrm{P}$, Lee TB. The effect of nedocromil sodium on the immediate response to antigen challenge in asthmatic patients. Clin Allergy 1986;16:129-34.

19 Dixon CMS, Fuller RW, Barnes PJ. The effect of nedocromil sodium on sulphur dioxide induced bronchoconstriction Thorax 1987;42:462-5.

20 Dixon CMS, Barnes PJ. Bradykinin induced bronchoconstriction: inhibitory effects of nedocromil sodium and cromolyn sodium. Am Rev Respir Dis 1988;137:A28 (abstr).

21 Hansson L, Choudry N, Fuller RW, Pride N. Effect of Nedocromil sodium on the airway response to inhaled capsaicin in normal subjects. Thorax 1988;43:935-6.

Accepted 3 April 1990 